\title{
Shipping routes in the South China Sea and northern Indian Ocean and associated monsoonal influences
}

\author{
Jau-Ming Chen ${ }^{1, *}$, Pei-Hua Tan ${ }^{2}$, Jin-Shuen Liu ${ }^{1}$, and Yi-Jang Shiau ${ }^{1}$ \\ ${ }^{1}$ Department of Maritime Information and Technology, National Kaohsiung Marine University, Kaohsiung City, Taiwan \\ ${ }^{2}$ Department of Applied History, National Chiayi University, Chiayi City, Taiwan
}

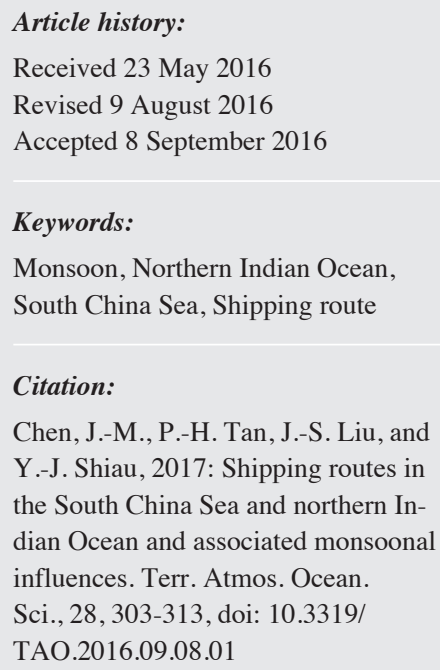

\begin{abstract}
The major shipping routes of the South China Sea (SCS) and northern Indian Ocean (NIO) are analyzed via ship observations compiled by the International Comprehensive Ocean-Atmosphere Data Set. In the SCS, one route from the East China Sea moves through the Taiwan Strait toward Hong Kong and Singapore. The other route from the Pacific moves passed the east coast of Taiwan and through the Bashi Channel/Luzon Strait to Singapore. After Singapore, the shipping routes pass through the Strait of Malacca to Sri Lanka. In the Arabian Sea, ships from Sri Lanka go either northwestward toward the Persian Gulf or westward toward the Red Sea. A northeast-southwest route connects the Persian Gulf and the Red Sea. The resultant routes exhibit a triangular pattern in the Arabian Sea. Monsoonal influences on shipping routes are evident in the Arabian Sea, but indiscernible in the SCS. In summer, the southwest monsoon causes strong winds and waves over the western-central Arabian Sea. Ships detour from the southern side of Socotra Island to the northern side. The northern side is on the leeside of the intruding southwesterly flows and has weaker winds and waves than the windward southern side. In the SCS, the winter northeasterly flows intensify winds and waves over two strait regions: the Taiwan Strait and the Luzon Strait. These straits are at the conjunction of the Pacific and the SCS. Routes passing through these straits have the advantage of a short, straight navigation path. Moreover, the winds and waves over these regions are not as strong as those occurring in the Arabian Sea during summer. The maritime conditions in the SCS are not dangerous enough to necessitate a detour.
\end{abstract}

\section{INTRODUCTION}

At present, the International Comprehensive OceanAtmosphere Data Set (ICOADS) is the largest available set of marine observations, dating back to 1784 (e.g., Parker et al. 2004; Woodruff et al. 2005; Kent et al. 2007). These data were compiled from the observation records of ships, buoys (fixed or drifting), and ocean stations. Ship records are obtained by either instrumental measurements or visual estimates. Due to changes in observation methods and recording practices across a period of about 200 years, ship observational data exhibit certain inhomogeneity (e.g., Minobe and Maeda 2005). Quayle (1980) compared surface wind measurements and estimates based upon ship observa-

\footnotetext{
* Corresponding author

E-mail:cjming@mail.nkmu.edu.tw
}

tions and found little agreement for lower wind speeds, but fair agreement for higher winds. Gulev (1999) compared traditional ship-recorded and newly employed instrumentmeasured surface winds and found that ship-recorded winds are overestimated for weak winds and underestimated for moderate and strong winds. In general, visually-estimated variables (e.g., ocean waves) are less reliable due to limits in quality control and potential human error in recording processes when compared with instrument-measured variables (e.g., winds and temperatures) (e.g., Worley et al. 2005). Throughout the past several decades, apparent strengthening of surface wind speed has been detected in the observational data from World War II (or about the 1950s) to the present. This time period correlates with the widespread employment of anemometers in place of sea-state estimates plus the operational use of an incorrect conversion from Beaufort force 
to wind speed (e.g., Peterson and Hasse 1987; Ramage 1987; Cardone et al. 1990). As such, the embedded uncertainty in ICOADS data reliability should lessen in periods closer to the present due to denser and more accurate sampling in observational operations (e.g., Worley et al. 2005).

In addition to surface meteorological observations, the ICOADS data also provide information on ship positions in each report recorded once every four hours, including date, longitude and latitude. (e.g., Woodruff et al. 2005). This information is considered highly accurate as it is recorded by well-experienced high-ranking officers. One key marine feature revealed by information on a ship's positions is major shipping routes. By interpreting seasonal frequency patterns based on accumulated ship-reported records from different ships, prevailing shipping routes over the North Pacific (NP) and North Atlantic (NA) are depicted by Chen et al. (2014). Following their approach, winteraccumulation frequency patterns computed from different ship records averaged from 1981 - 2010 ICOADS data in every $2^{\circ} \times 2^{\circ}$ grid over the Northern Hemisphere $(\mathrm{NH})$ are shown in Fig. 1. The path depicting the NP crossing between East Asia and North America is described as the great-circle route (e.g., Chen et al. 2014). This route begins from Taiwan/China and moves northeastward passing Japan and Kuril Island toward a point southeast of the Russian Kamchatka Peninsula. Ships then turn eastward along the $54^{\circ} \mathrm{N}$ latitude to the north of the Aleutian Islands toward the west coast of Canada and the United States of America. This great-circle route is taken mostly for safety and economics reasons. In terms of safety, the route is characterized by a path through the central region of the Aleutian low to avoid dangerous zones. These zones are described by high winds and strong waves at the southern boundary of the Aleutian low (south of $50^{\circ} \mathrm{N}$ ). Economically, an across-basin route following a great circle over the high latitudes is shorter in navigational distance than the low-latitude route due to the spherical nature of the Earth, meaning savings in fuel and time. In the NA, Chen et al. (2014) demonstrated that the major cross-basin routes were characterized by an X-shaped pattern, connecting North America/the Panama Canal on the western side of the Atlantic with the Mediterranean Sea/the British Isles and Europe on the eastern side. The X-shaped routes are located mainly in the oceans south of $40^{\circ} \mathrm{N}$ in winter to avoid strong winds and waves in the northern re- gions in company with the existence of the Icelandic low. In summer, additional routes appear in the southern (northern) region of the prevailing cross-NP (cross-NA) routes, reflecting the weakening of winds and waves associated with the decay of the Aleutian (Icelandic) low.

Figure 1 shows that a global route across the $\mathrm{NH}$ requires sailing across several major ocean basins: the NP, the NA, the northern Indian Ocean (NIO), and the South China Sea (SCS). In addition to the NP and NA, major shipping routes over the NIO and SCS and associated modulating effects from regional climate features have not been comprehensively studied. Both shipping routes over the NP and NA are in the high- and mid-latitude regions. Navigational safety is highly threatened by severe sea states caused by the Aleutian low in the NP (e.g., Terada and Hanzawa 1984; Fritz 1985; Zhang et al. 2004; Ahrens 2005; Rodionov et al. 2005) and by the Icelandic low in the NA (e.g., Sahsamanoglou 1990; Serreze et al. 1997; Ahrens 2005). As such, major shipping routes have to find ways to avoid dangerous marine environments during both the developing and mature stages of these lows in fall and winter (e.g., Chen et al. 2014). Different from previous studies on NP and NA shipping routes, paths across the NIO and SCS predominantly pass through tropical zones. These oceanic regions are not directly impacted by the Aleutian and Icelandic lows. They are primarily influenced by Asian monsoon systems. Climatologically, monsoon rainfall follows the emergence of southwesterly flows and first appears in the SCS in mid-May (i.e., the commencement of the East Asia summer monsoon) (e.g., Chang and Chen 1995; Chen and Chen 1995; Zhang et al. 2002; Wang et al. 2004). Rain-bands move northward during June and July in concurrence with the formation of the monsoonal frontal systems over East-Northeast Asia, and later shift to the tropical western North Pacific-Philippine Sea region in August (e.g., Chen 1994; Wang 1994; Lim et al. 2002; Wang and LinHo 2002; Wu 2002). In South Asia, the Indian monsoon causes major rainfall over the Indian subcontinent and the NIO (e.g., Ramage 1971; Krishnamurti 1978). Extended rain-bands first appear over the Maritime Continent during spring, move northward onto southern and southeastern Asian continental land and surrounding oceans in summer, before retreating southward during fall (e.g., Clift and Plumb 2008). The Indian summer monsoon concurs with the emergence of southwesterly flows from the westerly branch of

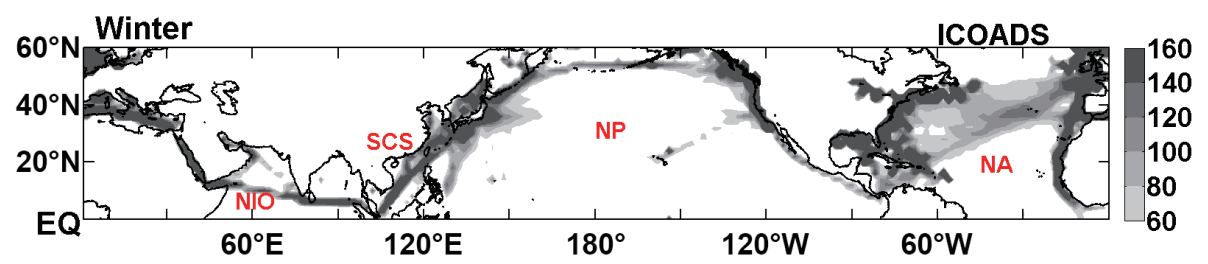

Fig. 1. The major shipping routes in the NH during winter represented by the accumulated numbers of ship-reported records compiled by ICOADS data averaged from 1981 - 2010. (Color online only) 
the Somali Jet after it leaves the coast of East Africa (e.g., Findlater 1969; Hastenrath 1991). The Somali Jet and its downstream flows over the NIO are responsible for a crossequatorial flux that transports abundant moisture from the tropics into the Arabian Sea and Bay of Bengal, leading to summer monsoon rainfall in these oceanic regions (e.g., Cadet and Reverdin 1981).

As reviewed above, the monsoonal climate of both the $\mathrm{NIO}$ and SCS during summer is noteworthy and would potentially have an impact on shipping routes. Therefore, it is worth investigating whether shipping routes in these regions exhibit salient changes due to monsoons. To this end, the main purpose of this study is to delineate the major shipping routes across the SCS and the NIO and explore how monsoonal systems may influence these routes. Major questions raised in this study are:

(1) What are the characteristics of major shipping routes across the SCS and the NIO?

(2) Does the monsoonal climate affect shipping routes? If so, what are the salient variability features?

Answers to the above questions can improve our understandings about the gross pictures of global shipping routes in the NH. Moreover, major climatic factors modulating regional shipping routes can be compared between tropical (NIO and SCS) and high-latitude (NP and NA) oceans. The identified controlling climatic features can serve as monitoring factors in weather and climate predictions associated with marine navigations for creating better shipping plans, improving marine safety and producing economic benefits.

\section{DATA}

Two datasets are analyzed in this study. The first dataset is the ICOADS data. These data are from marine observation records compiled in the user-friendly format of the International Maritime Meteorological Archive (IMMA; e.g., Woodruff et al. 2005). The IMMA format consists of core 108 digit data that includes the date, longitude, latitude, wind, pressure, wave, sea surface temperature, air temperature, and other meteorological variables. The analyses here only include data from ship reports to represent the shipping routes. Because ICOADS data are compiled from many different sources (e.g., buoy, ship, ocean station) and older data is less reliable than more recent data, this study utilizes data from 1981 - 2010. Data in the IMMA format are randomly distributed in space. Further, to construct a uniform spatial pattern, ICOADS data are converted to $1^{\circ} \times 1^{\circ}$ grid source regions covering both the NIO and SCS. For better matching of spatial resolution with the $1^{\circ}$-grid ICOADS variables, a second dataset is sourced. This dataset uses high-resolution National Centers for Environmental Prediction/Climate Forecast System Reanalysis (NCEP/CFSR) data (Saha et al. 2010). CFSR 10-m wind fields in a T382 Gaussian (about $0.3125^{\circ} \times 0.3125^{\circ}$ ) grid are used to delineate large-scale flow features associated with monsoon circulations. CFSR winds are compared with ICOADS winds to crosscheck the large-scale patterns depicted by ship-recorded data. Moreover, CFSR data can delineate wind direction that cannot be appropriately portrayed by ICOADS data due to significant record gaps.

\section{MONSOON CIRCULATIONS IN THE SCS AND NIO}

Both the SCS and NIO are influenced by a northeast monsoon in winter and southwest monsoon in summer (e.g., McGregor and Nieuwolt 1998; Robinson and HendersonSellers 1999; Chang et al. 2006; Trenberth et al. 2006). Climatological (1981 - 2010) seasonal means of CFSR 10-m winds $(V 10)$ are shown in Fig. 2 to depict the monsoon circulation features. The NIO analyzed here consists of the Arabian Sea and Bay of Bengal. Surface winds are dominated by
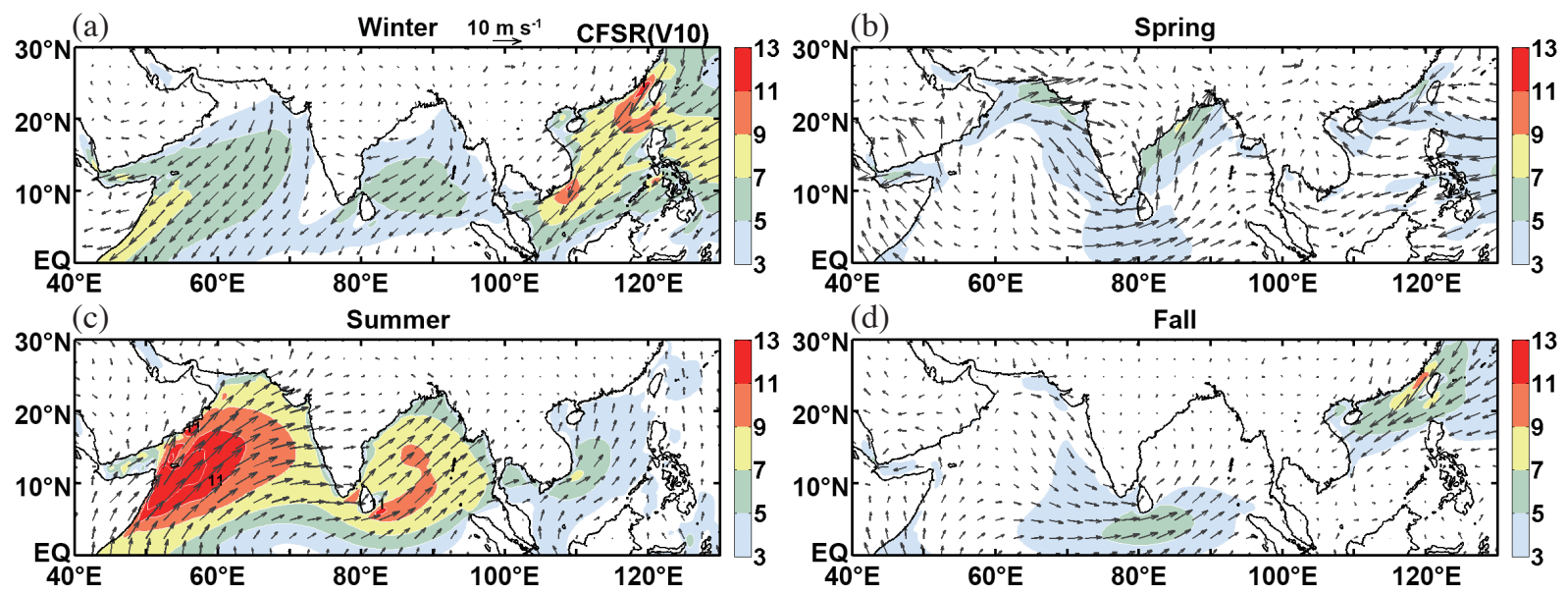

Fig. 2. The climatological (1981 - 2010) means of surface winds (10 m) computed from the CFSR data: (a) winter (DJF), (b) spring (MAM), (c) summer (JJA), and (d) fall (SON). Wind speeds are illustrated by shading (unit: $\mathrm{m} \mathrm{s}^{-1}$ ). 
northeasterly flows in winter (DJF) (Fig. 2a). Northeasterly flows from mid- and high-latitudes move into Southeast Asia and tropical regions when the Siberian high intensifies with a southward extension (e.g., Li and Yang 2010). They can easily move along the plains areas over eastern China and/or the East China Sea to reach the SCS. On the other hand, they have to overcome terrain barriers (Tibetan Plateau and Himalayas) in the north, the Indian subcontinent in the south, and Indochina in the east to reach the NIO. Northeasterly flows are therefore stronger over the SCS than over the NIO. In the SCS region, strong winds occur near Taiwan, particularly over the Taiwan Strait and oceans to the southwest/south of Taiwan. In spring (MAM), both the Arabian Sea and Bay of Bengal feature southerly flows over the western boundary of the ocean basin (Fig. 2b). Stronger surface winds tend to move along the coast of the Indian subcontinent. In the SCS easterly flows original from the southern section of the Pacific subtropics prevail. Overall, flows over the NIO and SCS are weaker in spring than in winter.

In summer (JJA), the southwest monsoon prevails in the SCS and NIO (Fig. 2c). Cross-equatorial flows move from the Southern Hemisphere into the NH. One salient feature is the Somali Jet. Its strong winds flow northward along the coast of East Africa. This jet turns northeastward over the western parts of the Arabian Sea and eastward over the eastern parts. It merges with cross-equatorial flows from the south to form southwesterly flows over the Bay of Bengal. The eastward extension of strong winds becomes less recognizable in the SCS. In general, wind speed is strong in the Arabian Sea, moderate in the Bay of Bengal and weak in the SCS. In fall (SON), flow patterns in the NIO (Fig. 2d) partially resemble those in spring, featuring surface flows moving around the coast of the Indian subcontinent. However, the winds tend to be stronger in spring than fall over the NIO. The SCS flow patterns in fall are similar to those in winter, featuring strong northeasterly winds in the northern
SCS reaching a maximum in the Taiwan Strait.

Overall, surface winds exhibit noticeable monsoonal features in the NIO and SCS; i.e., a southwest monsoon in summer and northeast monsoon in winter. The northeasterly monsoonal flows are stronger in the SCS than in the NIO, while the southwesterly monsoonal flows are stronger in the NIO than in the SCS. Monsoon features in spring and fall are indiscernible in surface wind fields.

\section{MAJOR SHIPPING ROUTES IN THE SCS AND NIO}

Accumulated ship-report numbers from ICOADS data are used to interpret the major shipping routes in the NP and NA (e.g., Chen et al. 2012, 2014). Adopting the above approach, climatological (1981 - 2010) means of seasonally accumulated frequency patterns computed from ICOADS data were used to delineate major shipping routes in the SCS and NIO. In winter (Fig. 3a), shipping routes in the SCS exhibit two major paths separated by Taiwan. One route passes from the East China Sea via the southeastern coast of China/Taiwan Strait to reach Hong Kong. Afterward, the route turns southwestward toward Singapore. The other route sails from the western Pacific along the eastern coast of Taiwan to pass the Bashi Channel/Luzon Strait and then heads southwestward toward Singapore. The above two routes merge in the central SCS at a point around $111^{\circ} \mathrm{E}$, $11^{\circ} \mathrm{N}$. After Singapore, the major route passes through the Strait of Malacca along a westbound path toward Sri Lanka and onward into the Arabian Sea. The major shipping routes form a triangular pattern after entering the Arabian Sea. They go from Sri Lanka with a northwestward path toward the Persian Gulf or take a westward path toward the Red Sea. The third side of the triangular pattern is a route that moves along the coast of the Arabian Peninsula to connect the Persian Gulf with the Red Sea.
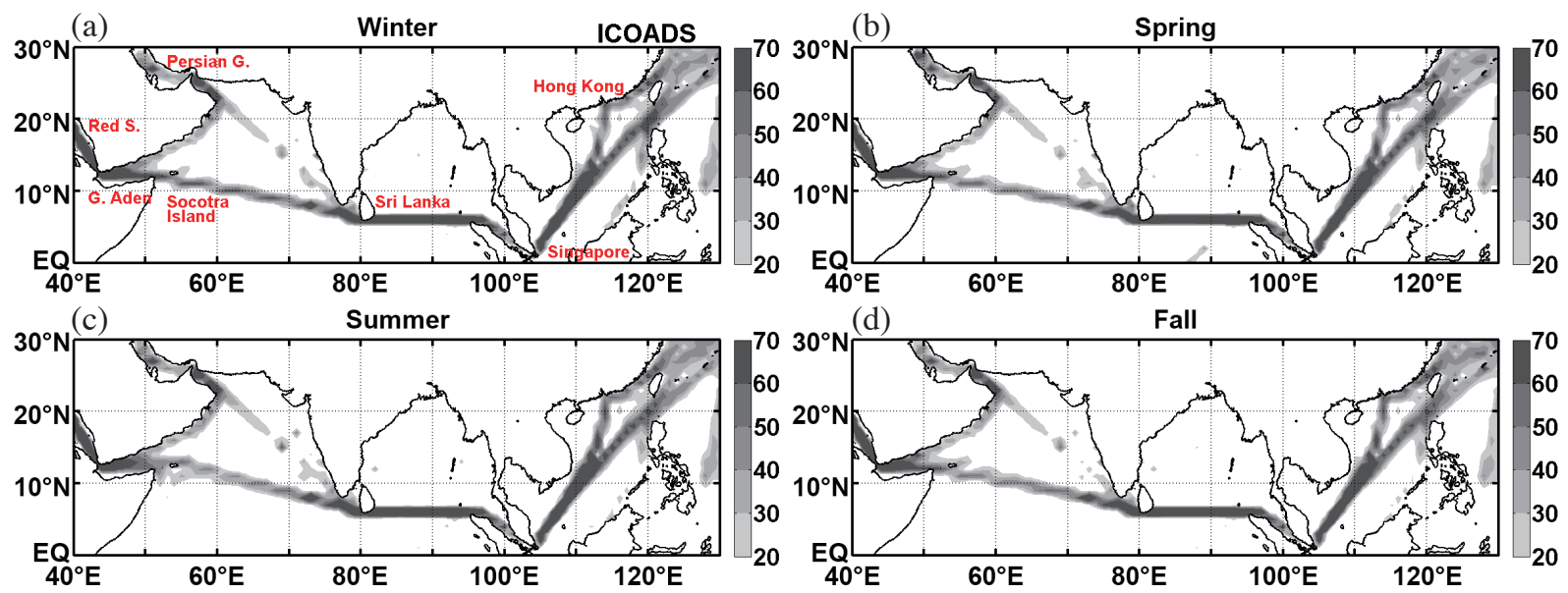

Fig. 3. As in Fig. 1, except for the major seasonal shipping routes in the NIO and the SCS averaged from the 1981 - 2010 ICOADS data: (a) winter, (b) spring, (c) summer, and (d) fall. (Color online only) 
The major shipping routes in spring, summer and fall (Figs. 3b - d) exhibit a pattern similar to that of winter. The locations of the various destination ports determined the major routes. The similarity between these routes in different seasons suggests that the weather and sea conditions are relatively stable throughout the year. This is different from the high-latitude routes in the NP and NA, which exhibit evident meridional changes in shipping routes to avoid severe sea states caused by seasonal circulations (e.g., Chen et al. 2014). However, there is one noticeable route change in Fig. 3. In the Arabian Sea, the major route passes by Socotra Island $\left(53.83^{\circ} \mathrm{E}, 12.48^{\circ} \mathrm{N}\right)$ via its southern side in winter, spring and fall, but via its northern side in summer. This island is in a region significantly influenced by the Somali Jet in summer months (see Fig. 2c). This suggests influences from the southwest monsoon on this shipping route across the Arabian Sea. The northeasterly monsoon is strong in the northern SCS region during winter (see Fig. 2a) but the major shipping routes in the SCS do not exhibit any noticeable variability between summer and winter. The northeast monsoon does not exert evident influences on the shipping routes over the SCS. The northeast and southwest monsoons seem to impose different degrees of influence on major shipping routes in the NIO and SCS. The climatic marine environments in these two ocean regions and the associated effects are discussed in the next section.

\section{MARINE CLIMATE IN THE SCS AND NIO}

Navigational safety is highly affected by strong winds and high waves (e.g., Chen et al. 2012). Marine climates associated with seasonal shipping routes in the SCS and NIO are investigated using surface winds and ocean waves based on ship observations. Figure 4 shows the climatological (1981 - 2010) means of surface winds from ICOADS data. Among the four seasons, ICOADS surface winds exhibit strong winds (larger than $7 \mathrm{~m} \mathrm{~s}^{-1}$ ) in three seasons. The first case is nearby Taiwan during winter extending from the Taiwan Strait to the oceans off the southwest-south coast of Taiwan (Fig. 4a). Strong winds also occur over oceans off the southeast coast of the Indochina Peninsula. The second case is nearby Socotra Island during summer when strong winds extend from the coast of East Africa and the Arabian Peninsula eastward to the central part of the Arabian Sea (Fig. 4c). The Somali Jet strongly influences this area. The third case is in the Taiwan Strait during fall (Fig. 4d). Strong winds appearing near Taiwan during fall and winter occur due to the northeast monsoon.

The ICOADS wave climatological means compiled for the four seasons are displayed in Fig. 5. Chen et al. (2014) studied shipping routes in the NP and NA and found that climatological-mean wave height greater than or equal to $2.5 \mathrm{~m}$ is considered a potential threat to navigational safety. Ships take precautions in these regions (e.g., detours). There are several regions identified with strong waves in the seasonal-mean patterns in this study. Strong waves in winter and fall are narrowly constrained to a region nearby Taiwan, across the Taiwan Strait and the oceans off the southeastsouth coast of Taiwan (Figs. 5a and d). These waves fall within a range of $2-2.5 \mathrm{~m}$. Strong waves in summer expand largely over the western-central Arabian Sea. The waves can be stronger than $3 \mathrm{~m}$ (Fig. 5c). By comparing salient features between Figs. 4 and 5, it is easy to see that regions and seasons with strong waves and strong winds are spatially and temporally consistent. The northeast monsoon worsens marine environments for shipping during fall and winter near Taiwan, while the southwest monsoon causes threats to shipping in the Arabian Sea during summer. We investigate the respective influences of the southwest and northeast monsoons on regional shipping routes further below.

\section{MONSOONAL INFLUENCES ON SHIPPING ROUTES IN THE NIO}

Evident changes in shipping routes occur during summer near Socotra Island over the Arabian Sea in association with the strong winds and high waves. These results suggest that the southwest monsoon exerts substantial influence on NIO shipping routes via changes in marine climate. The detailed shipping route changes are indicated by the monthly shipping routes over the Arabian Sea from April to September (Fig. 6). These routes are represented by the climatological means of monthly-accumulated frequency computed from ship records of ICOADS data. In April, the shipping route connecting the Red Sea and Sri Lanka passes through the oceans on the southern side of Socotra Island. In May, the major route is still through waters south of the island, but the frequency of passes through the northern side increases. In June, the frequency of passes through the northern side of the island dominates the southern side. In July and August, the shipping passes primarily through waters on the northern side of the island. In September, the majority of shipping uses the southern side of the island with some ships taking the northern route. These patterns indicate that May and September are transitional months for shipping between the northern and southern sides of Socotra Island.

The seasonal marine climate associated with the shifts in shipping routes around Socotra Island is examined using ICOADS surface wind and ocean wave data, and CFSR surface wind data. The CFSR surface wind climatological monthly means averaged over the northern and southern sides of Socotra Island $\left(53.83^{\circ} \mathrm{E}, 12.48^{\circ} \mathrm{N}\right)$ are shown in Fig. 7. The northern region is in the $53-55^{\circ} \mathrm{E}, 13-14^{\circ} \mathrm{N}$ domain, while the southern region is in the $53-55^{\circ} \mathrm{E}, 11$ $-12^{\circ} \mathrm{N}$ domain. Also compared the climatological monthlymean surface winds and ocean waves of ICOADS data in the same regions. The CFSR surface winds (Fig. 7a) reveal a clear seasonal cycle. The winds start to intensify in May and 
reach maximum intensity during the summer with greater speed in the southern region $\left(13.3-14.8 \mathrm{~m} \mathrm{~s}^{-1}\right)$ than in the northern region $\left(10.8-12.6 \mathrm{~m} \mathrm{~s}^{-1}\right)$. Winds begin to decay in September and remain weak in the remaining months of the year. As shown in Fig. 2c, the southern side of Socotra Island is under the direct influence of southwesterly flows associated with the Somali Jet. Socotra Island blocks the winds on the northern side of the island and thus weakens the wind intensity. The ICOADS surface winds (Fig. 7b) exhibit a seasonal cycle resembling that in the CFSR data, except they are weaker in intensity. During summer, ICOADS winds range about $8.5-9.5 \mathrm{~m} \mathrm{~s}^{-1}$ in the northern region and $9.5-10.8 \mathrm{~m} \mathrm{~s}^{-1}$ in the southern region. Overall, ICOADS winds are about $71-79 \%$ the intensity of CFSR winds. Ships are normally required to take a route avoiding severe oceanic environments as much as possible. Ship observations to some extent reflect a safe environment, leading to an underestimation in wind intensity when compared with the actual data. Chen et al. (2014) compared winter climatologic surface wind means between NCEP reanalysis and ICOADS data and found evidently weaker winds for ICOADS data in the tropical NP. Their results are consistent with our results that show weaker winds in ICOADS data than in CFSR data over the tropical Indian Ocean.

The ICOADS waves in Fig. 7c are also strong in summer, with higher waves in the southern region $(2.9-3.1 \mathrm{~m})$ than in the northern region $(2.5-3.0 \mathrm{~m})$. As indicated by the above analyses, the change in major shipping routes around Socotra Island during summer appears to concur with the fast and significant intensification of surface winds and ocean waves caused by the southwest monsoon emergence on the windward southern side of the island. Shipping thus tends to find a safer and more efficient route to the north of the island. On the southern side of Socotra Island, ocean waves during summer are about 2.9 - $3.1 \mathrm{~m}$, while CFSR winds are $13.3-14.8 \mathrm{~m} \mathrm{~s}^{-1}$. These values suggest that climatological ocean waves higher than $2.9 \mathrm{~m}$ and climatological CFSR winds stronger than $13.3 \mathrm{~m} \mathrm{~s}^{-1}$ could represent conditions for a potentially dangerous environment under which requires a detour in shipping routes as precautionary action.

\section{MONSOON AND SHIPPING ROUTES IN THE SCS}

Shipping routes in the SCS seem to show no evident route change over seasons (Fig. 3). However, strong winds and high waves do occur near Taiwan in accordance with northeast monsoon intensification during fall and winter (Figs. 4 and 5). The climatological monthly-mean surface winds and ocean waves over the Taiwan Strait $\left(119-120^{\circ} \mathrm{E}\right.$, $\left.24-25^{\circ} \mathrm{N}\right)$ and Luzon Strait $\left(120-121^{\circ} \mathrm{E}, 19-21^{\circ} \mathrm{N}\right)$ are shown in Fig. 8. CFSR surface winds (Fig. 8a) averaged from these two strait regions exhibit a similar seasonal cycle, strong in fall and winter and weak in spring and summer. From October to February, CFSR winds reach a speed of $7.7-10.5 \mathrm{~m} \mathrm{~s}^{-1}$ over the Luzon Strait and $10.4-12.0 \mathrm{~m} \mathrm{~s}^{-1}$ over the Taiwan Strait. ICOADS winds (Fig. 8b) display a seasonal cycle similar to that of CFSR winds, except with weaker intensity. Strong winds from October to February have a speed of $6.2-7.5 \mathrm{~m} \mathrm{~s}^{-1}$ over the Luzon Strait and 8.7 - $9.7 \mathrm{~m} \mathrm{~s}^{-1}$ over the Taiwan Strait. ICOADS winds are about $70-85 \%$ the intensity of CFSR winds. ICOADS waves in these two strait regions display a seasonal cycle resembling that of surface winds. Strong waves occur from October to February at a height of $1.7-2.2 \mathrm{~m}$ in the Luzon Strait and of $2.3-2.5 \mathrm{~m}$ in the Taiwan Strait.

Shipping routes in the SCS encounter the worst marine environments in two strait regions connecting the SCS and the Pacific: the Taiwan Strait and Luzon Strait. High waves raised by the northeast monsoon persist in fall and winter, with a maximum of $2.5 \mathrm{~m}$ in the Taiwan Strait and $2.2 \mathrm{~m}$ in the Luzon Strait. These two values are clearly smaller than
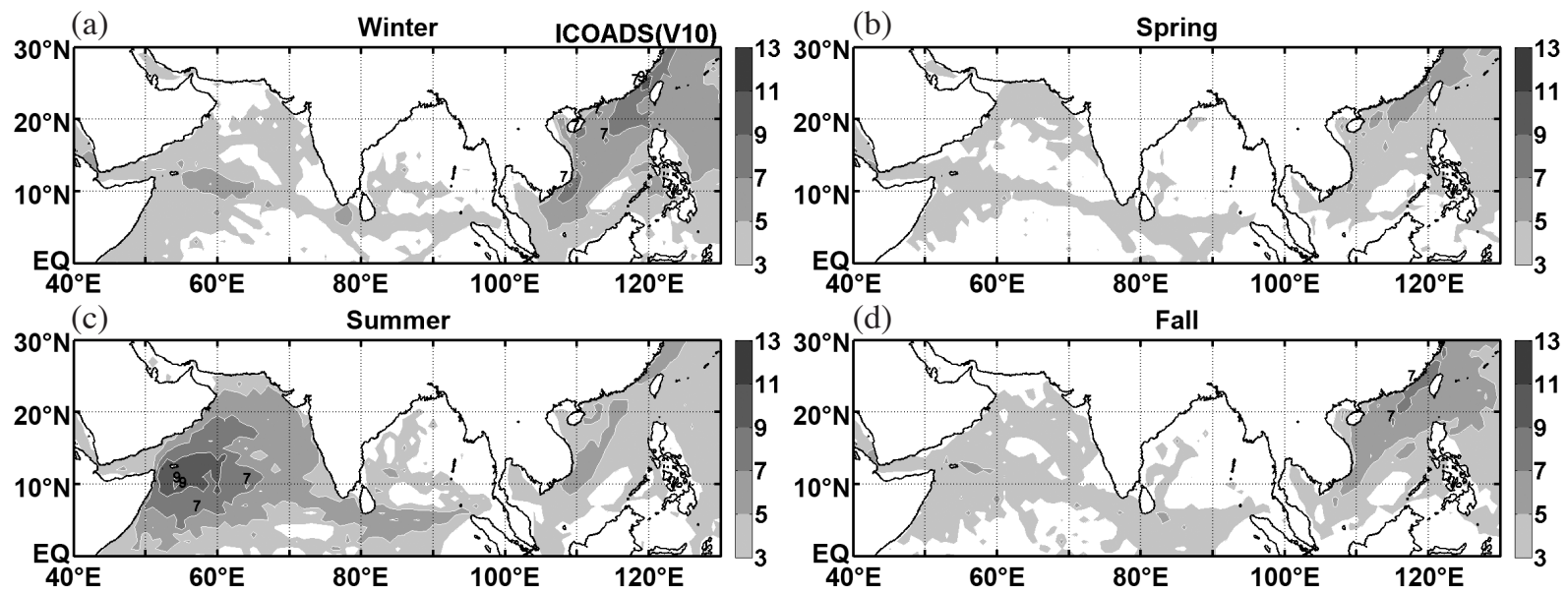

Fig. 4. As in Fig. 2, except for the climatological means of surface winds computed from the 1981 - 2010 ICOADS data: (a) winter, (b) spring, (c) summer, and (d) fall. 

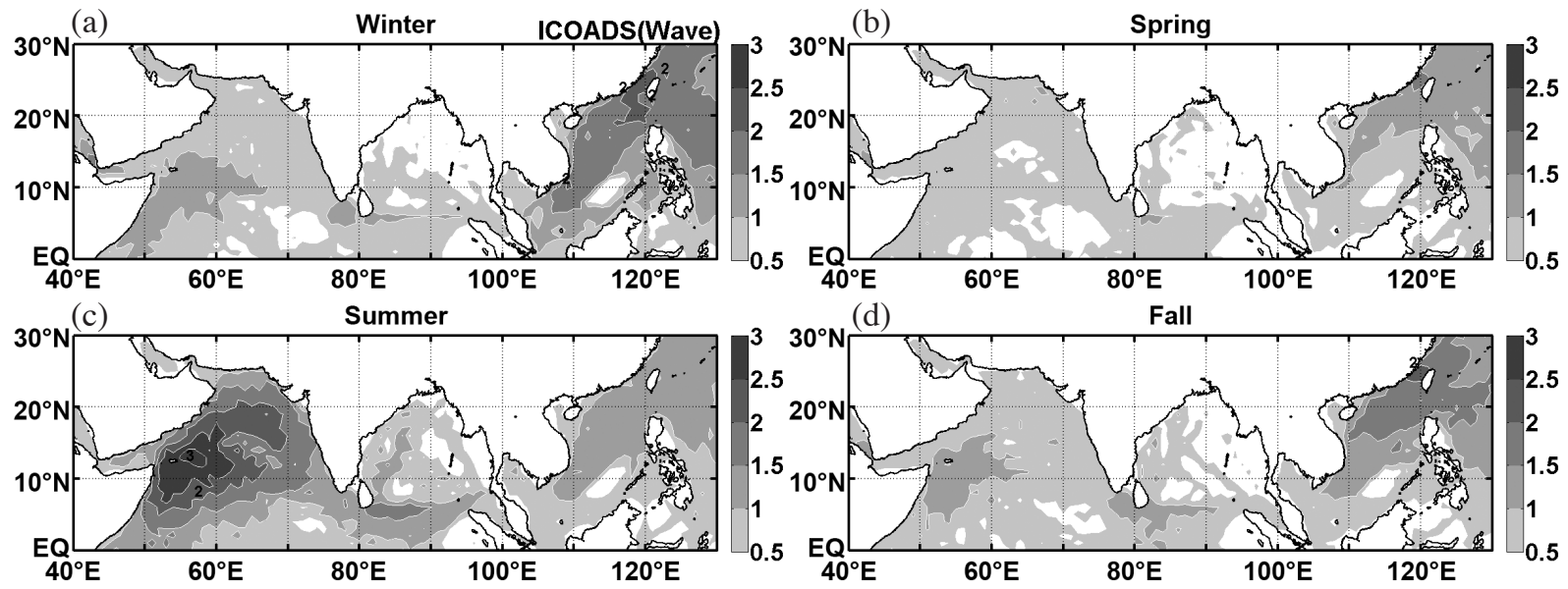

Fig. 5. As in Fig. 2, except for the climatological means of ocean waves computed from the 1981 - 2010 ICOADS data: (a) winter, (b) spring, (c) summer, and (d) fall.
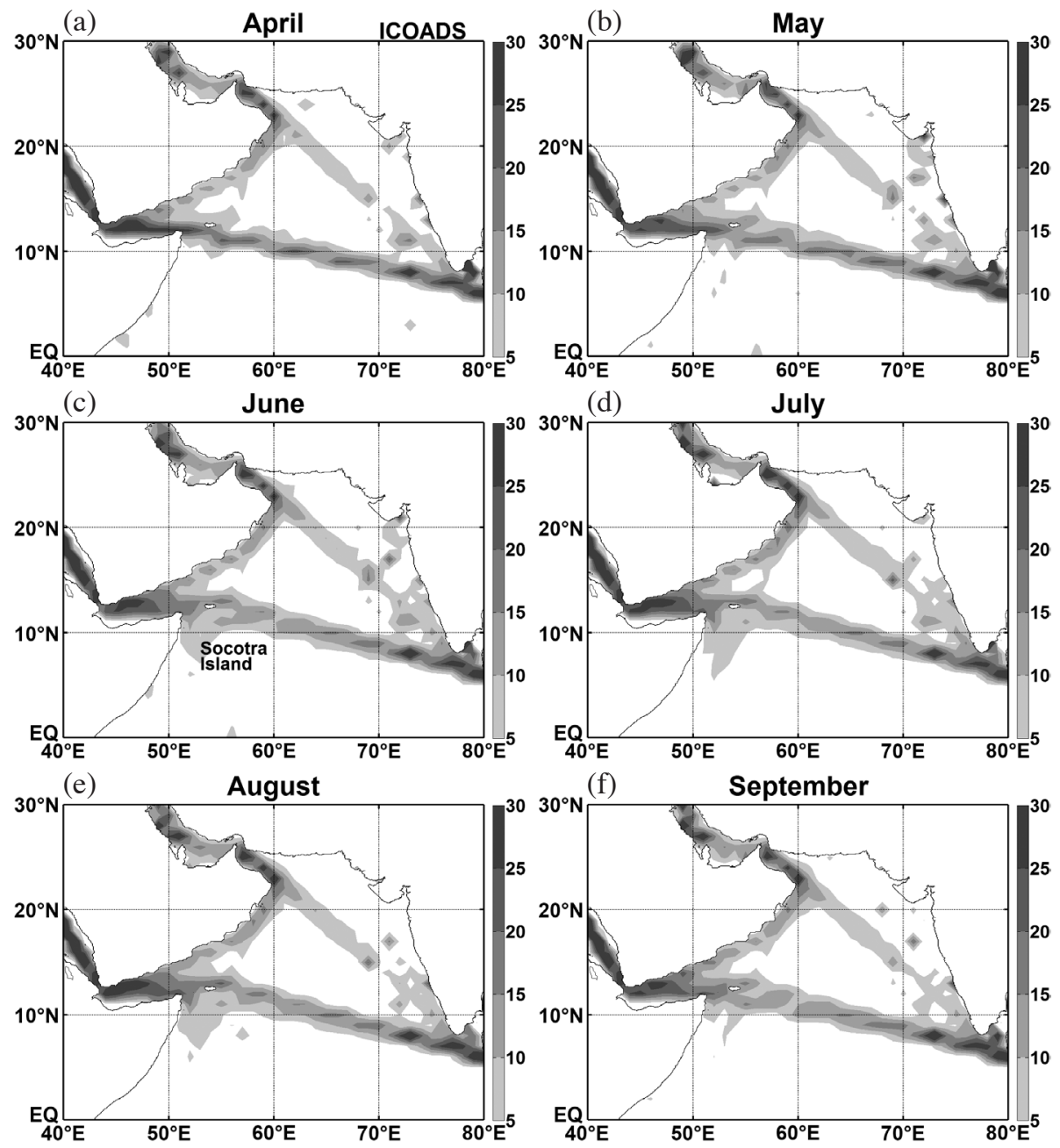

Fig. 6. As in Fig. 3, except for the monthly shipping routes in the Arabian Sea averaged from the 1981 - 2010 ICOADS data: (a) April, (b) May, (c) June, (d) July, (e) August, and (f) September. 

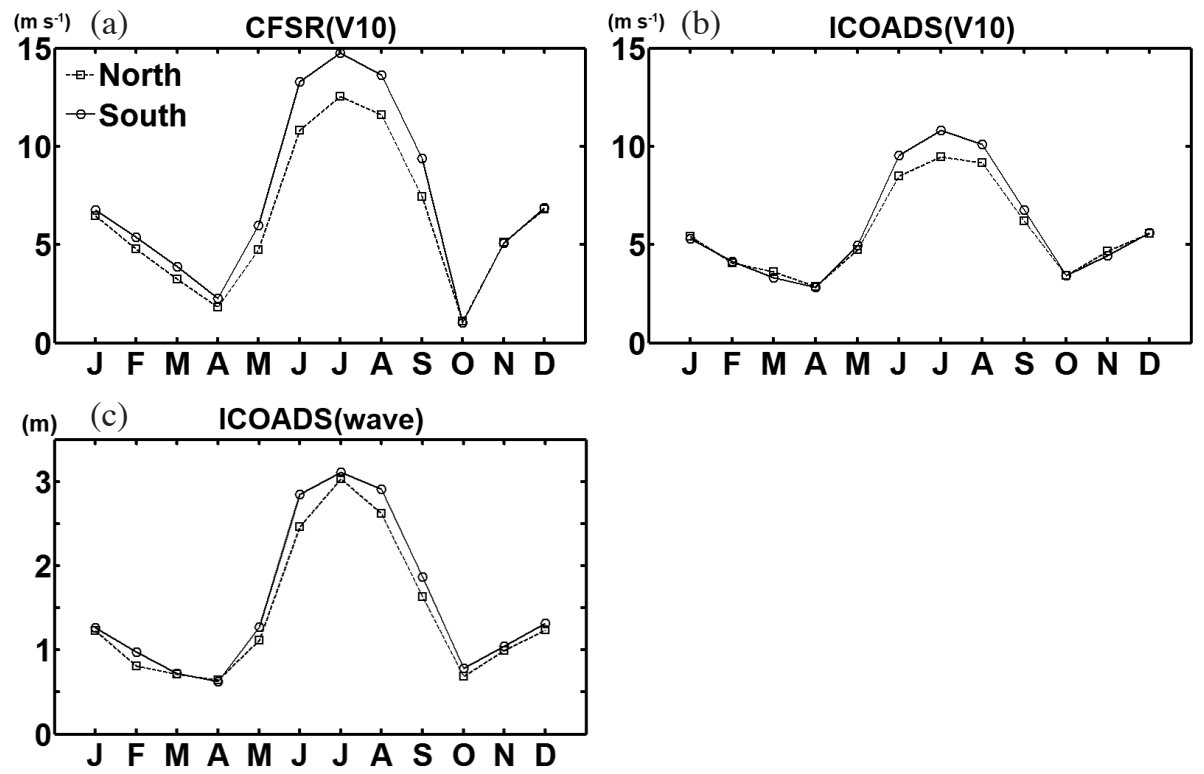

Fig. 7. The climatological (1981 - 2010) means of monthly marine states on the northern side $\left(53-55^{\circ} \mathrm{E}, 13-14^{\circ} \mathrm{N}\right)$ and the southern side $\left(53-55^{\circ} \mathrm{E}\right.$, $11-12^{\circ} \mathrm{N}$ ) of the Socotra Island: (a) CFSR surface winds, (b) ICOADS surface winds, and (c) ICOADS ocean waves.
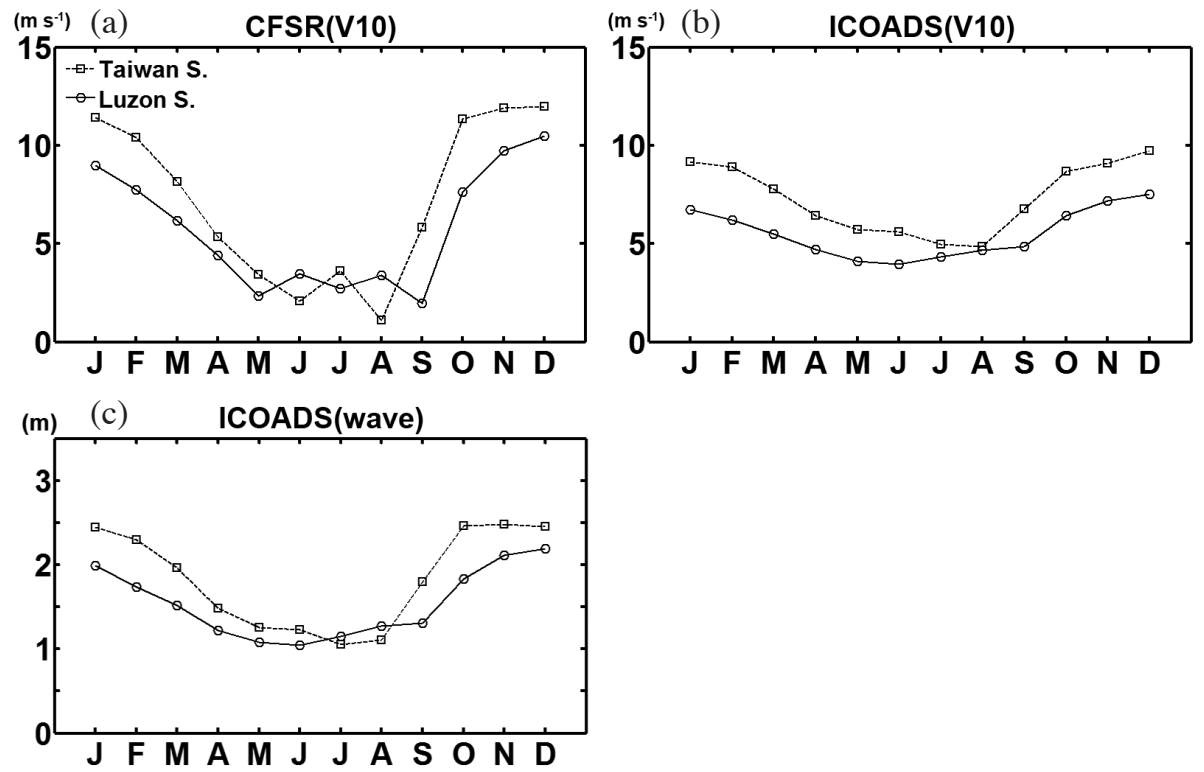

Fig. 8. The climatological (1981 - 2010) means of monthly marine states in the Taiwan Strait $\left(119-120^{\circ}\right.$ E, $\left.24-25^{\circ} \mathrm{N}\right)$ and the Luzon Strait $(120$ $121^{\circ} \mathrm{E}, 19-21^{\circ} \mathrm{N}$ ): (a) CFSR surface winds, (b) ICOADS surface winds, and (c) ICOADS ocean waves.

the potentially dangerous conditions found in the Arabian Sea $(2.9 \mathrm{~m})$. CFSR winds have a maximum of $12.0 \mathrm{~m} \mathrm{~s}^{-1}$ in the Taiwan Strait and $10.5 \mathrm{~m} \mathrm{~s}^{-1}$ in the Luzon Strait. These wind speeds are smaller than the potentially dangerous level of $13.3 \mathrm{~m} \mathrm{~s}^{-1}$ found on the southern side of Socotra Island. Based upon the Arabian Sea example, marine environments over the Taiwan Strait and Luzon Strait are not dangerous enough for shipping to seek an alternative route through these two straits. A common commercial practice in ship- ping is to plan a route with a navigational distance as short as possible. Other than these two straits, no substitute route can be found connecting the Pacific and the SCS in a comparably distance efficient or near efficient scenario. The above analyses of climatic and economic motivations show no reason for changing shipping route during the northeast monsoon. As such, shipping routes connecting the Pacific and SCS that pass through the Taiwan Strait and Luzon Strait do persist in all seasons regardless of the prevailing monsoon. 


\section{CONCLUDING REMARKS}

ICOADS data were used to analyze shipping routes over the SCS and NIO (including the Bay of Bengal and Arabian Sea) using 1981 - 2010 ship observations. These routes connect the NP and the NA to complete global routes in the NH. Accumulated ship record frequency patterns interpreted the major shipping routes. The major shipping routes in the SCS undergo two tracks. One is from the East China Sea via the southeast coast of China and the Taiwan Strait toward Hong Kong before heading southwestward to Singapore. The other is from the Pacific via the east coast of Taiwan passing the Bashi Channel/Luzon Strait before heading southwestward toward Singapore. The above two routes merge in the central SCS at a point around $111^{\circ} \mathrm{E}$, $11^{\circ} \mathrm{N}$. Shipping routes continue from Singapore via the Strait of Malacca to Sri Lanka. After entering the Arabian Sea, the major shipping routes form a triangular pattern. They go from Sri Lanka with a northwestward path toward the Persian Gulf or follow a westward path toward the Red Sea. The third side of the triangular pattern is a route that moves with a northeast-southwest path to connect the Persian Gulf with the Red Sea.

Asian monsoons influence both the SCS and NIO. The northeast monsoon affects the SCS in fall and winter, while the southwest monsoon influences the Arabian Sea in summer. The intensified monsoonal flows and accompanying high waves cause worsened marine environments, which pose a potential threat to navigational safety. In summer, the southwest monsoon features the appearance of the Somali Jet, whose strong winds induce strong waves across the east coast of East Africa to the western Arabian Sea. Ships sailing between Sri Lanka and the Red Sea detour from their conventional route on the southern side of Socotra Island to its northern side to avoid severe marine conditions. The northern side is on the leeside of these southwesterly flows, ensuring weaker winds and waves compared to the southern side. This detour occurs mainly during summer (JJA) due to the southwest monsoon.

In the SCS and NIO, severe transient events (e.g., cyclones and typhoons) may occur from time to time. The marine insurance policy usually requires international shipping vessels to be equipped with weather routing that provides updated weather prediction information plus optimal route suggestions to increase shipping efficiency and prevent weather-related incidents. Ship crews are therefore aware of existing and/or developing severe weather events in advance. Changes in shipping plan (e.g., detour) are executed as a precautionary action. Climatologically, cyclones and typhoons do not occur often in the analysis domain. Their impacts on detours are not significant enough to affect the summer shipping route climatological patterns.

Analyses by Heij and Knapp (2015) showed that international shipping over the Indian Ocean is carried out using three types of ships: general cargo vessels (about 31.4\%), containerships (about 22.4\%), and oil tankers (about 24\%). Containerships and oil tankers normally have a large gross tonnage over $50 \mathrm{~K}$, while general cargo vessels have a small tonnage ranging about $5-20 \mathrm{~K}$. They also showed that the ratio for weather-related incidents is about $0.3 \%$ for general cargo vessels and only $0.02 \%$ for containerships sailing across the Indian Oceans. Such risks increase significantly by a ratio of $9.5 \%$ for general cargo vessels when the wave height increases by one standard deviation from the climatological mean during spring and summer. The risks do not increase significantly for containerships. A larger ship can better resist severe oceanic environments. The critical height for hazardous waves varies in accordance with the ship size. Stronger waves in the regions south of Socotra Island may impose larger potential threat to shipping safety, particularly for a small ship. In order to comply with the insurance policy requirement to take a safer route, most ships follow a major route along the northern side of Socotra Island during summer.

Shipping routes in the SCS encounter intensified northeasterly flows and strong waves near Taiwan during fall and winter, specifically, the Taiwan Strait to the west and the Bashi Channel/Luzon Strait to the south. However, the major shipping routes in these two strait regions do not exhibit evident route changes for two reasons. First, the Taiwan Strait and Luzon Strait are at the conjunction connecting the Pacific and the SCS. As shipping routes, they offer the shortest navigational distance, saving navigational time and fuel cost. Second, enhanced winds and waves in these two strait regions during fall and winter are not strong enough to discourage the use of these routes unlike in the Arabian Sea during summer. In other words, the winter marine conditions in the SCS are not dangerous enough for ships to take a necessary detour. No evident influence was found on shipping routes from the northeast monsoon in the SCS.

In terms of climatic influences on shipping routes in the NH connecting the NP, SCS, NIO, and NA, controlling climatic factors differ among ocean basins. In the NP and NA, high-latitude climatic features strongly influence shipping routes. The appearance of the Aleutian low during winter forces ships farther north (about $54^{\circ} \mathrm{N}$ ) along the central region of the low to avoid strong winds and high waves in the southern boundary of the low. This route is beneficial as it offers a shorter navigational distance between East Asia and North America due to Earth's spherical shape. In the NA, the existence of the Icelandic low in winter restricts shipping in the regions south of $40^{\circ} \mathrm{N}$ as ships avoid strong winds and high waves caused by the low in the northern region. Unlike the NP and NA, shipping routes in the NIO and SCS are influenced by low-latitude features, specifically, Asian monsoons. The summer southwest monsoon induces worsened marine conditions in the NIO forcing a detour in shipping from the southern side of Socotra Island in the 
Arabian Sea to its northern side. The northeast monsoon causes rough sea states at the junction between the Pacific and the SCS during winter. However, these conditions are not severe enough to avert shipping. The results from this study advance our understanding of how monsoon-related climatic conditions influence shipping efficiency and safety in tropical oceans.

Acknowledgements The authors would like to thank the anonymous reviewers for their valuable comments to improve this paper. This Ministry of Science and Technology, Taiwan, supported this study under Grants MOST 1042111-M-022-001.

\section{REFERENCES}

Ahrens, C. D., 2005: Essentials of Meteorology: An Invitation to the Atmosphere, $4^{\text {th }}$ Edition, Thomson Brooks/ Cole, Singapore, 473 pp.

Cadet, D. and G. Reverdin, 1981: The monsoon over the Indian Ocean during summer 1975. Part I: Mean fields. Mon. Weather Rev., 109, 148-158, doi: 10.1175/15200493(1981)109<0148:TMOTIO>2.0.CO;2. [Link]

Cardone, V. J., J. G. Greenwood, and M. A. Cane, 1990: On trends in historical marine wind data. J. Climate, $\mathbf{3}$, 113-127, doi: 10.1175/1520-0442(1990)003<0113:OT IHMW>2.0.CO;2. [Link]

Chang, C. P. and G. T. J. Chen, 1995: Tropical circulations associated with southwest monsoon onset and westerly surges over the South China Sea. Mon. Weather Rev., 123, 3254-3267, doi: 10.1175/1520-0493(1995)123<3 254:TCAWSM>2.0.CO;2. [Link]

Chang, C. P., Z. Wang, and H. Hendon, 2006: The Asian winter monsoon. In: Wang, B. (Ed.), The Asian Monsoon, Springer Praxis Books, Springer Berlin Heidelberg, 89-127, doi: 10.1007/3-540-37722-0_3. [Link]

Chen, G. T. J., 1994: Large-scale circulations associated with the East Asian summer monsoon and the Mei-Yu over South China and Taiwan. J. Meteorol. Soc. Jpn., 72, 959-983, doi: 10.2151/jmsj1965.72.6_959. [Link]

Chen, J. M., C. M. Hsieh, and J. S. Liu, 2012: Possible influences of ENSO on winter shipping in the North Pacific. Terr. Atmos. Ocean. Sci., 23, 397-411, doi: 10.3319/ TAO.2012.03.02.01(A). [Link]

Chen, J. M., P. H. Tan, C. M. Hsieh, J. S. Liu, H. S. Chen, L. H. Hsu, and J. L. Huang, 2014: Seasonal climate associated with major shipping routes in the North Pacific and North Atlantic. Terr. Atmos. Ocean. Sci., 25, 381400, doi: 10.3319/TAO.2013.12.31.01(A). [Link]

Chen, T. C. and J. M. Chen, 1995: An observational study of the South China Sea monsoon during the 1979 summer: Onset and life cycle. Mon. Weather Rev., 123, 2295-2318, doi: 10.1175/1520-0493(1995)123<2295: AOSOTS $>2.0 . \mathrm{CO} ; 2$. [Link]
Clift, P. D. and R. A. Plumb, 2008: The Asian Monsoon: Causes, History and Effects, Cambridge University Press, 288 pp, doi: 10.1017/CBO9780511535833. [Link]

Findlater, J., 1969: Interhemispheric transport of air in the lower troposphere over the western Indian Ocean. Q. J. R. Meteorol. Soc., 95, 400-403, doi: 10.1002/ qj.49709540412. [Link]

Fritz, S., 1985: The Aleutian low in January and FebruaryRelation to tropical Pacific sea surface temperature. Mon. Weather Rev., 113, 271-275, doi: 10.1175/15200493(1985)113<0271:TALIJA>2.0.CO;2. [Link]

Gulev, S. K., 1999: Comparison of COADS release 1a winds with instrumental measurements in the Northwest Atlantic. J. Atmos. Ocean. Technol., 16, 133-145, doi: 10.1175/1520-0426(1999)016<0133:COCRWW> 2.0.CO;2. [Link]

Hastenrath, S., 1991: Climate Dynamics of the Tropics, Springer Netherlands, 488 pp, doi: 10.1007/978-94011-3156-8. [Link]

Heij, C. and S. Knapp, 2015: Effects of wind strength and wave height on ship incident risk: Regional trends and seasonality. Transport. Res. Transport Environ., 37, 29-39, doi: 10.1016/j.trd.2015.04.016. [Link]

Kent, E. C., S. D. Woodruff, and D. I. Berry, 2007: Metadata from WMO publication No. 47 and an assessment of Voluntary Observing Ship observation heights in ICOADS. J. Atmos. Ocean. Technol., 24, 214-234, doi: 10.1175/JTECH1949.1. [Link]

Krishnamurti, T. N., 1978: Monsoon Dynamics, Birkhäuser Basel, 443 pp, doi: 10.1007/978-3-0348-5759-8. [Link]

Li, Y. and S. Yang, 2010: A dynamical index for the East Asian winter monsoon. J. Climate, 23, 4255-4262, doi: 10.1175/2010JCLI3375.1. [Link]

Lim, Y. K., K. Y. Kim, and H. S. Lee, 2002: Temporal and spatial evolution of the Asian summer monsoon in the seasonal cycle of synoptic fields. J. Climate, 15, 36303644, doi: 10.1175/1520-0442(2002)015<3630:TASE OT>2.0.CO;2. [Link]

McGregor, G. R. and S. Nieuwolt, 1998: Tropical Climatology: An Introduction to the Climates of the Low Latitudes, $2^{\text {nd }}$ Edition, John Wiley \& Sons, $352 \mathrm{pp}$.

Minobe, S. and A. Maeda, 2005: A $1^{\circ}$ monthly gridded seasurface temperature dataset compiled from ICOADS from 1850 to 2002 and Northern Hemisphere frontal variability. Int. J. Climatol., 25, 881-894, doi: 10.1002/ joc.1170. [Link]

Parker, D. E., E. C. Kent, S. D. Woodruff, D. Denhenauw, D. E. Harrison, T. Manabe, M. Mietus, V. R. Swail, and S. J. Worley, 2004: The second JCOMM workshop on advances in Marine Climatology (CLIMARII). WMO Bull., 53, 157-159.

Peterson, E. W. and L. Hasse, 1987: Did the Beaufort scale or the wind climate change? J. Phys. Oceanogr., 17, 
1071-1074, doi: 10.1175/1520-0485(1987)017<1071: DTBSOT>2.0.CO;2. [Link]

Quayle, R. G., 1980: Climatic comparisons of estimated and measured winds from ships. J. Appl.Meteorol., 19, 142-156, doi: 10.1175/1520-0450(1980)019<0142:CC OEAM>2.0.CO;2. [Link]

Ramage, C. S., 1971: Monsoon Meteorology, Academic Press, 296 pp.

Ramage, C. S., 1987: Secular change in reported surface wind speeds over the ocean. J. Clim. Appl. Meteorol., 26, 525-528, doi: 10.1175/1520-0450(1987)026<0525 :SCIRSW>2.0.CO;2. [Link]

Robinson, P. J. and A. Henderson-Sellers, 1999: Contemporary Climatology, Routledge, $332 \mathrm{pp}$.

Rodionov, S. N., J. E. Overland, and N. A. Bond, 2005: The Aleutian low and winter climatic conditions in the Bering Sea. Part I: Classification. J. Climate, 18, 160177, doi: 10.1175/JCLI3253.1. [Link]

Saha, S., S. Moorthi, H. Pan, X. Wu, J. Wang, S. Nadiga, P. Tripp, R. Kistler, J. Woollen, D. Behringer, H. Liu, D. Stokes, R. Grumbine, G. Gayno, J. Wang, Y. Hou, H. Chuang, H.H. Juang, J. Sela, M. Iredell, R. Treadon, D. Kleist, P. Van Delst, D. Keyser, J. Derber, M. Ek, J. Meng, H. Wei, R. Yang, S. Lord, H. Van Den Dool, A. Kumar, W. Wang, C. Long, M. Chelliah, Y. Xue, B. Huang, J. Schemm, W. Ebisuzaki, R. Lin, P. Xie, M. Chen, S. Zhou, W. Higgins, C. Zou, Q. Liu, Y. Chen, Y. Han, L. Cucurull, R.W. Reynolds, G. Rutledge, and M. Goldberg, 2010: The NCEP Climate Forecast System reanalysis. Bull. Amer. Meteorol. Soc., 91, 10151057, doi: 10.1175/2010BAMS3001.1. [Link]

Sahsamanoglou, H. S., 1990: A contribution to the study of action centres in the North Atlantic. Int. J. Climatol., 10, 247-261, doi: 10.1002/joc.3370100303. [Link]

Serreze, M. C., F. Carse, R. G. Barry, and J. C. Rogers, 1997: Icelandic low cyclone activity: Climatological features, linkages with the NAO, and relationships with recent changes in the Northern Hemisphere circulation. J. Climate, 10, 453-464, doi: 10.1175/1520-044 2(1997)010<0453:ILCACF>2.0.CO;2. [Link]

Terada, K. and M. Hanzawa, 1984: Climate of the North
Pacific Ocean. In: Van Loon, H. (Ed.), Climates of the Oceans, World Survey of Climatology, Elsevier, 431-477.

Trenberth, K. E., J. W. Hurrell, and D. P. Stepaniak, 2006: The Asian monsoon: Global perspectives. In: Wang, B. (Ed.), The Asian Monsoon, Springer Praxis Books, Springer Berlin Heidelberg, 67-87, doi: 10.1007/3540-37722-0_2. [Link]

Wang, B., 1994: Climatic regimes of tropical convection and rainfall. J. Climate, 7, 1109-1118, doi: 10.1175/15 20-0442(1994)007<1109:CROTCA>2.0.CO;2. [Link]

Wang, B. and LinHo, 2002: Rainy season of the Asian-Pacific summer monsoon. J. Climate, 15, 386-398, doi: 10.1175/1520-0442(2002)015<0386:RSOTAP>2.0.C O;2. [Link]

Wang, B., LinHo, Y.Zhang, and M. M.Lu, 2004: Definition of South China Sea monsoon onset and commencement of the East Asia summer monsoon. J. Climate, 17, 699-710, doi: 10.1175/2932.1. [Link]

Woodruff, S. D., H. F. Diaz, S. J. Worley, R. W. Reynolds, and S. J. Lubker, 2005: Early ship observational data and ICOADS. Clim. Change, 73, 169-194, doi: 10.1007/s10584-005-3456-3. [Link]

Worley, S. J., S. D. Woodruff, R. W. Reynolds, S. J. Lubker, and N. Lott, 2005: ICOADS release 2.1 data and products. Int. J. Climatol., 25, 823-842, doi: 10.1002/ joc.1166. [Link]

$\mathrm{Wu}, \mathrm{R} ., 2002$ : Processes for the northeastward advance of the summer monsoon over the western North Pacific. J. Meteorol. Soc. Jpn., 80, 67-83, doi: 10.2151/ jmsj.80.67. [Link]

Zhang, X., J. E. Walsh, J. Zhang, U. S. Bhatt, and M. Ikeda, 2004: Climatology and interannual variability of Arctic cyclone activity: 1948-2002. J. Climate, 17, 23002317, doi: 10.1175/1520-0442(2004)017<2300:CAIV OA>2.0.CO;2. [Link]

Zhang, Y., T. Li, B. Wang, and G. Wu, 2002: Onset of the summer monsoon over the Indochina Peninsula: Climatology and interannual variations. J. Climate, $\mathbf{1 5}$, 3206-3221, doi: 10.1175/1520-0442(2002)015<3206: OOTSMO $>2.0 . \mathrm{CO} ; 2$. [Link] 